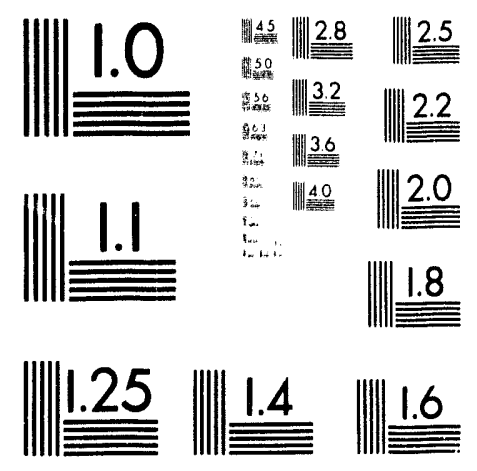



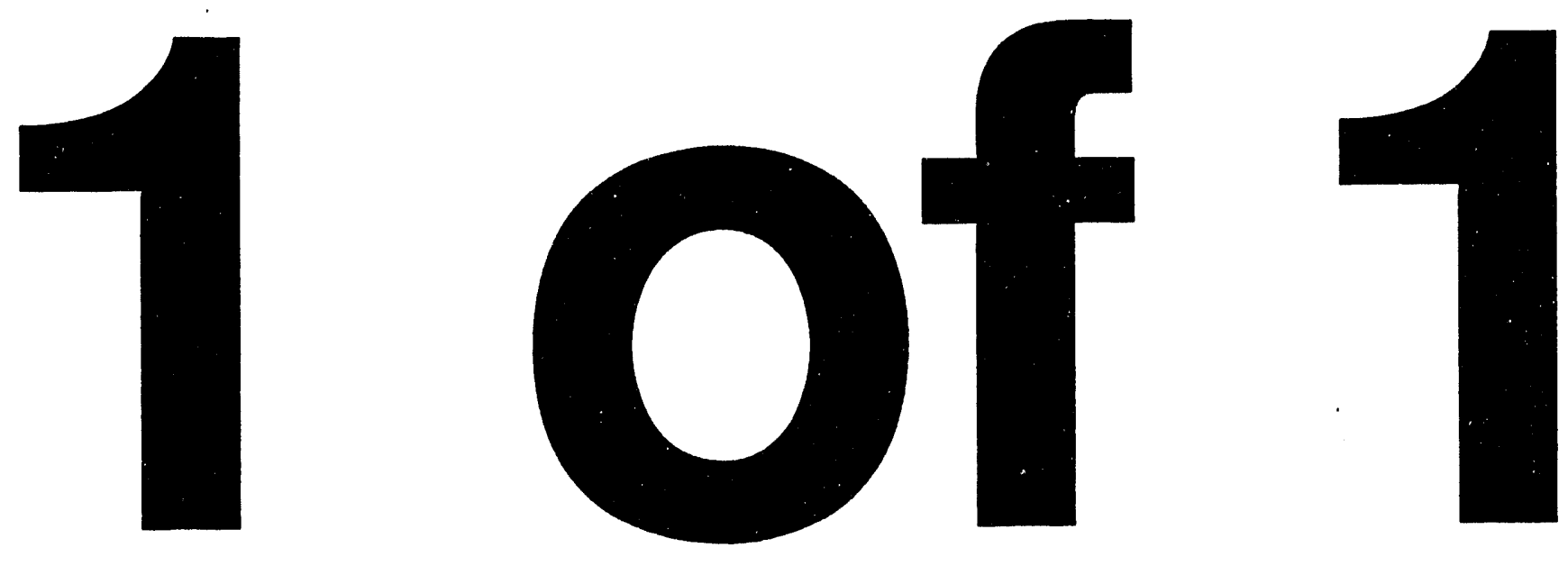


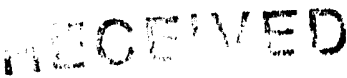

NOV $2 ? 1993$

OSTI

\title{
AnNuAl RePORT ON THE U.S. DEPARTMENT OF ENERGY'S Cultural Resource Activities at Colorado UMTRA Project Sites FOR OCTOBER 1991 THROUGH SEPTEMBER 1992
}

\author{
Draft
}

\section{October 1993}

\section{DISCLAIMER}

This report was prepared as an account of work sponsored by an agency of the United States Government. Neither the United States Government nor any agency thereof, nor any of their employees, makes any warranty, express or implied, or assumes any legal liabilis, product, or bility for the accuracy, completeness, or usefulness of any information, appaned rights. Referprocess disclosed, or represents that its use would not infinge prive by trade name, trademark, ence herein to any specific commercial product, process, or service by trade name, traterecommanufacturer, or otherwise does not necessarily constitute or imply its endoreof. The views mendation, or favoring by the United States Government or any agency thereor. The vithe

and opinions of authors expressed herein do not
United States Government or any agency thereof. 


\section{NOTE}

This report includes legal locations of cultural resources that were identified during cultural resource surveys. Please limit distribution of this report to protect the cultural resources from vandalism. 


\section{ANNUAL REPORT ON THE U.S. DEPARTMENT OF ENERGY'S CULTURAL RESOURCE ACTIVITIES AT COLORADO UMTRA PROJECT SITES FOR OCTOBER 1991 THROUGH SEPTEMBER 1992}

October 1993

Prepared for

Adyisory Council on Historic Preservation

Colorado State Historic Preservation Officer

Prepared by

Jacobs Engineering Group Inc.

Albuquerque, New Mexico 


\section{ABSTRACT}

This report summarizes the U.S. Department of Energy's (DOE) cultural resource studies that were undertaken in support of the DOE's Uranium Mill Tailings Remedial Action (UMTRA) Project in the state of Colorado for the period of October 1, 1991, through September 30,1992 . This report fulfills the DOE's obligation to provide an annual report to the state of Colorado on the status and results of cultural resource studies conducted during the above period of record. This requirement is stated in a programmatic memorandum of agreement executed between the DOE, the Advisory Council on Historic Preservation, and the Colorado State Historic Preservation Officer in December 1984. Previous reports were based on a calendar year reporting period. However, in order to be more consistent with the programmatic memorandum of agreement, the period of record for this and subsequent annual reports has been changed to the Federal fiscal year.

The current status and summaries of 1992 cultural resource surveys are provided for all UMTRA Project sites in Colorado. The sites are Durango, Grand Junction, Gunnison, Maybell, Naturita, Rifle, and Slick Rock. 


\section{TABLE OF CONTENTS}

\section{Section}

Page

1.0 INTRODUCTION $\ldots \ldots \ldots \ldots \ldots \ldots \ldots \ldots \ldots \ldots \ldots \ldots \ldots \ldots \ldots$

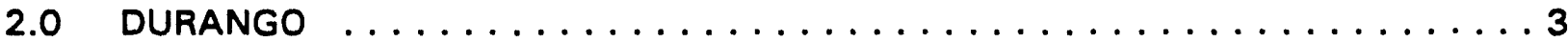

2.1 Status of cultural resource activities $\ldots \ldots \ldots \ldots \ldots \ldots \ldots \ldots$

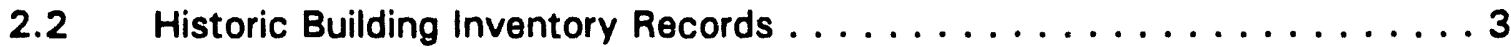

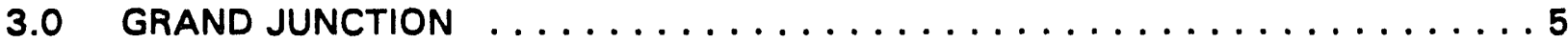

3.1 Status of cultural resource activities $\ldots \ldots \ldots \ldots \ldots \ldots \ldots \ldots$

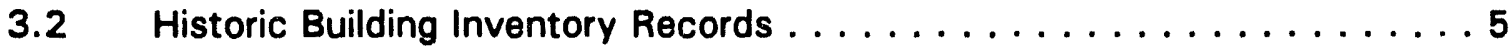

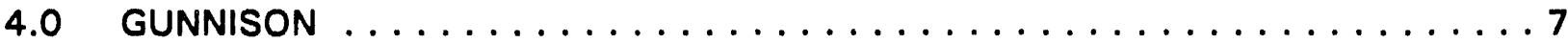

4.1 Status of cultural resource activities $\ldots \ldots \ldots \ldots \ldots \ldots \ldots$

4.2 Historic Building Inventory Records . . . . . . . . . . . . . 10

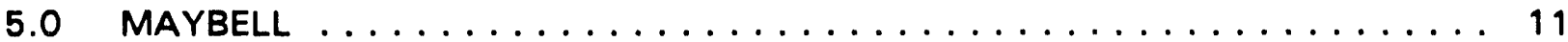

5.1 Status of cultural resource activities $\ldots \ldots \ldots \ldots \ldots \ldots \ldots \ldots$

5.2 Historic Building Inventory Records . . . . . . . . . . . . 11

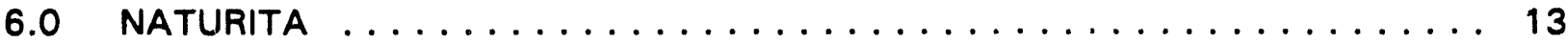

6.1 Status of cultural resource activities $\ldots \ldots \ldots \ldots \ldots \ldots \ldots \ldots$

6.2 Historic Building Inventory Records . . . . . . . . . . . . . 13

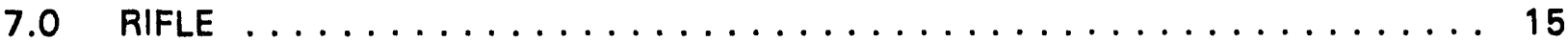

7.1 Status of cultural resource activities $\ldots \ldots \ldots \ldots \ldots \ldots \ldots$

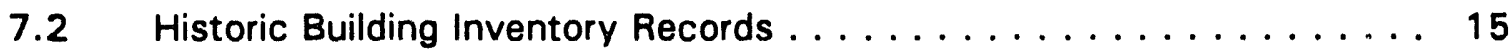

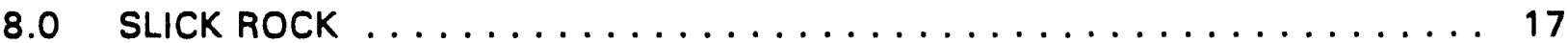

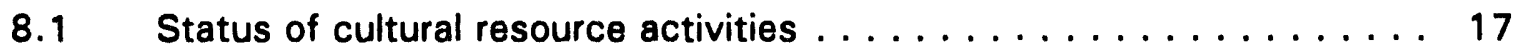

8.2 Historic Building Inventory Records . . . . . . . . . . . . . 17

9.0 LIST OF CONTRIBUTORS $\ldots \ldots \ldots \ldots \ldots \ldots \ldots \ldots \ldots \ldots \ldots$

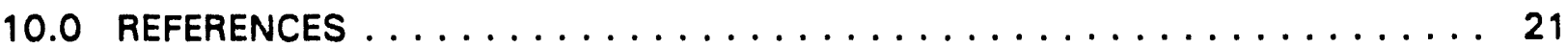


ANNUAL REPORT ON THE U.S. DEPARTMENT OF ENERGY'S CULTURAL

\section{LIST OF FIGURES}

\section{Figure}

Page

4.1 Locations of areas surveyed for cultural resources along the Tenderf yot Mountain transportation route .................... 8

4.2 Location of site $5 \mathrm{GN} 810 \ldots \ldots \ldots \ldots \ldots \ldots \ldots \ldots$ 


\section{LIST OF ACRONYMS AND ABBREVIATIONS}

$\begin{array}{ll}\text { Acronym } & \text { Definition } \\ \text { ac } & \text { acre } \\ \text { DOE } & \text { U.S. Department of Energy } \\ \text { EA } & \text { environmental assessment } \\ \text { EIS } & \text { environmental impact statement } \\ \text { GRI } & \text { Grand River Institute } \\ \text { HBIR } & \text { Historic Building Inventory Records } \\ \text { ha } & \text { hectare } \\ \text { NRHP } & \text { National Register of Historic Places } \\ \text { PMOA } & \text { programmatic memorandum of agreement } \\ \text { SHPO } & \text { State Historic Preservation Officer } \\ \text { UMTRA } & \text { Uranium Mill Tailings Remedial Action } \\ \text { VP } & \text { vicinity property }\end{array}$




\subsection{INTRODUCTION}

This report summarizes the cultural resource investigations conducted at the U.S. Department of Energy's (DOE) Uranium Mill Tailings Remedial Action (UMTRA) Project sites in Colorado. The UMTRA Project is a cooperative (state and Federal) remedial action project mandated by Public Law 95-604, the Uranium Mill Tailings Radiation Control Act, to clean up 24 inactive uranium mill tailings sites throughout the United States. Nine of these sites are in Colorado.

On December 6, 1984, the DOE, the Advisory Council on Historic Preservation, and the Colorado State Historic Preservation Officer (SHPO) entered into a programmatic memorandum of agreement (PMOA) (DOE, 1984). The PMOA specifies procedures by which the DOE shall fulfill its obligations under the various state and Federal regulations for cultural and historic resource preservation. The PMOA requires an annual report; this report summarizes the UMTRA Project cultural resource investigations in Colorado for the Federal fiscal year 1992.

This report is organized by site. It summarizes the status of general site activities, the cultural resource investigations, Historic Building Inventory Records (HBIR) that were completed for 1992, and, when known, the DOE's plans for cultural resource activities in 1993. 


\subsection{DURANGO}

The final environmental impact statement (EIS) for the Durango UMTRA Project site was published in October 1985; the selected remedial action was to relocate all contaminated materials by truck to the Bodo Canyon disposal site. The remedial action was begun in 1987 and completed in 1991.

\subsection{STATUS OF CULTURAL RESOURCE ACTIVITIES}

Cultural resource activities related to the Durango remedial action were completed in 1988. The Durango remedial action was completed in 1991, and no additional cultural resource activities are anticipated for this UMTRA Project site.

\section{$2.2 \quad$ HISTORIC BUILDING INVENTORY RECORDS}

All included vicinity properties (VP) and processing site remedial actions for Durango have been completed; therefore, there were no HBIR activities. 


\subsection{GRAND JUNCTION}

The final EIS for the Grand Junction UMTRA Project site was published in December 1986. The selected remedial action is to relocate all contaminated materials by a combination of truck and rail transportation to the Cheney disposal site. Remedial action began in 1991; it is anticipated that all tailings materials and most of the VP materials will be stabilized at the Cheney disposal site by 1994.

\section{$3.1 \quad$ STATUS OF CULTURAL RESOURCE ACTIVITIES}

Cultural resource activities for the Grand Junction remedial action were completed in 1990. No additional cultural resource activities are anticipated for this UMTRA Project site.

\subsection{HISTORIC BUILDING INVENTORY RECORDS}

The Grand Junction UMTRA Project site has an estimated 4224 VPs, of which about 3929 had been cleaned up by the end of 1992. Six HBIRs were completed and submitted to the SHPO in 1992. All of these properties were exempt from historic preservation review, as outlined in Appendix $A$ of the PMOA (DOE, 1984). The remedial action of these properties did not affect their potential historic significance. Additional HBIRs are expected in subsequent years until all VPs are completed. 


\subsection{GUNNISON}

The final environmental assessment (EA) for the Gunnison UMTRA Project site was published in 1992; the selected remedial action is to relocate all contaminated materials by truck to the Landfill disposal site. Remedial action began in 1992 and is anticipated to be completed in 1995.

\subsection{STATUS OF CULTIJRAL RESOURCE ACTIVITIES}

Two cultural resource surveys were undertaken in the Gunnison area in 1992 by Grand River Institute (GRI).

An intensive Class III cultural resource inventory of 30 acres (ac) [1 2 hectares (ha)] was conducted in November 1991 and May 1992. Two areas were surveyed to determine whether two segments of the proposed Tenderfoot Mountain transportation route could be realigned to avoid known cultural resources. Two discrete areas, comprising $25 \mathrm{ac} \mathrm{(10} \mathrm{ha)} \mathrm{and} 5$ ac ( $2 \mathrm{ha}$ ) and labeled Alternative 7 and Alternative 8 , respectively, were evaluated (Figure 4.1). A 100 percent, pedestrian Class III cultural resource survey of the study area was conducted by one person walking a zigzag transect that covered a 200-foot (60-meter) wide corridor. No cultural resources were identified during the survey. It was recommended that the alternate route segments be used instead of the original alignment in order to avoid disturbing known cultural resources or conducting additional studies. It was also recommended that, due to the proximity of the known cultural resources, initial construction work along these routes be monitored (GRI, 1992a).

The second cultural resource survey was an evaluative testing of site 5GN810. This site is described as an extensive open lithic-scatter/campsite. It had been recorded in 1980 and appeared to be outside the area of construction for the proposed Tenderfoot Mountain transportation route (Figure 4.2). During field inspections in April 1992, GRI and Bureau of Land Management archaeologists determined that the site overlapped the proposed road. Testing for this site included surface mapping and collection of all artifacts within the construction area and subsurface testing, as determined necessary in the field. The primary goals were to determine the vertical and horizontal extent of cultural resources and to define the nature of the deposits (GRI, 1992b).

It was determined that a section of the area to be affected by the proposed road upgrading is part of a larger, previously unrecorded ephemeral locus within the larger site area. Artifacts were encountered primarily as surface manifestations and included portions of projectile points, obsidian flakes, and chipped stone tools. During excavations, a rock-lined hearth was found that contained carbon layers. All surface artifacts in the area potentially disturbed by road construction were collected, and the area to be directly affected by construction activities was field evaluated as not eligible for listing on the National Register of Historic Places (NRHP). The area to the north in which the hearth was located 

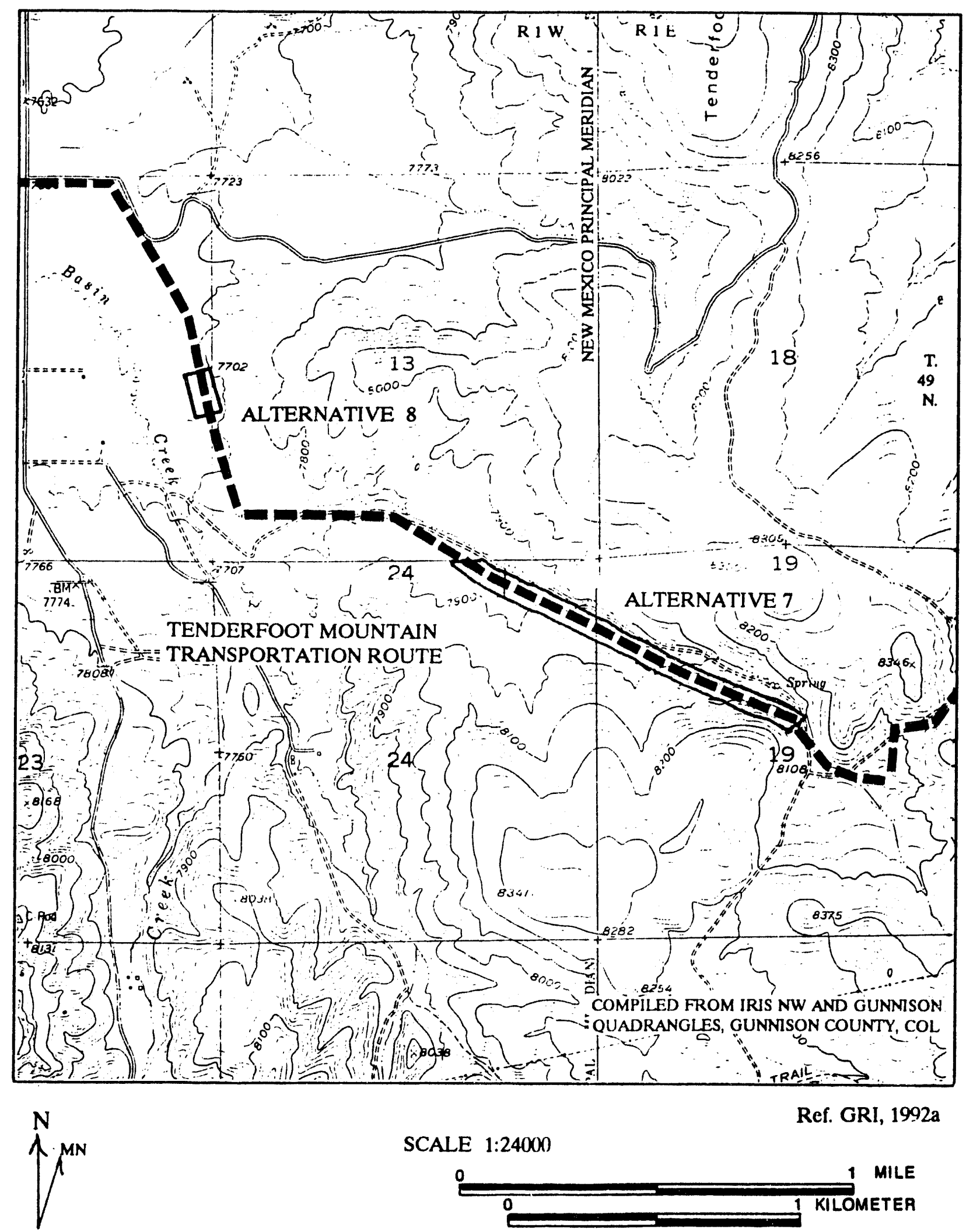

SCALE 1:24000

Ref. GRI, 1992a

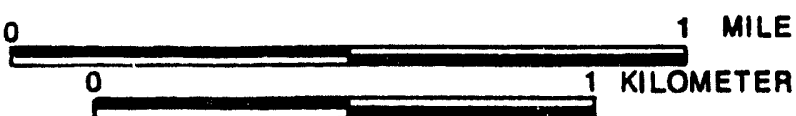

FIGURE 4.1

LOCATIONS OF AREAS SURVEYED FOR CULTURAL RESOURCES ALONG THE TENDERFOOT MOUNTAIN TRANSPORTATION ROUTE 

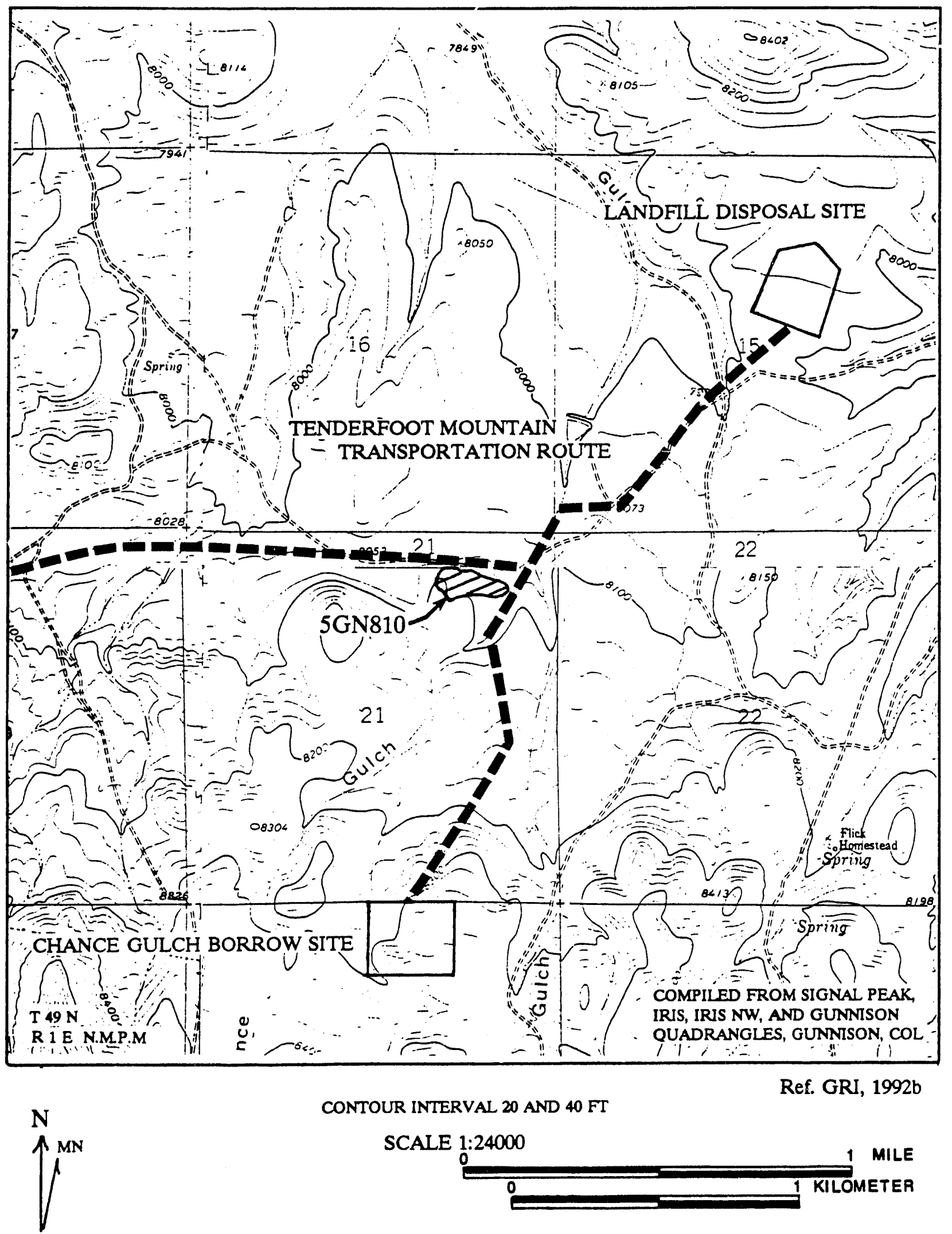

CONTOUR INTERVAL 20 AND $40 \mathrm{FT}$

Ref. GRI, 1992b

SCALE 1:24000

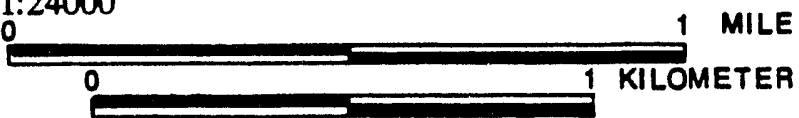

FIGURE 4.2

LOCATION OF SITE 5GN810 
(and excavated) appears to have the potential for additional cultural resources to be found. The site area in general was evaluated as eligible for listing un the NRHP. To ensure integrity of the area, monitoring was recommended for this portion of the road (GRI, 1992b).

\subsection{HISTORIC BUILDING INVENTORY RECORDS}

No HBIRs were submitted for VPs associated with the Gunnison UMTRA site. 


\subsection{MAYBELL}

A draft EA on the proposed remedial action for the Maybell UMTRA Project site was under preparation in 1992. The proposed remedial action is to stabilize all coritaminated materials at the location of the existing tailings pile. Remedial action is anticipated to begin in 1994.

\subsection{STATUS OF CULTURAL RESOURCE ACTIVITIES}

No cultural resource activities were conducted at the Maybell UMTRA site in 1992. Additional surveys may be conducted before remedial activities begin, should there be a potential to disturb previously unsurveyed areas or the four sites previously identified.

\subsection{HISTORIC BUILDING INVENTORY RECORDS}

There are no VPs present or associated with the Maybell UMTRA Project site. 


\subsection{NATURITA}

A draft EA on the proposed remedial action for the Naturita UMTRA Project site is scheduled to be completed in 1993. The proposed remedial action is to relocate all contaminated materials to a proposed disposal site named Dry Flats. Remedial action is anticipated to begin in 1994.

\section{$6.1 \quad$ STATUS OF CULTURAL RESOURCE ACTIVITIES}

No cultural resource activities were conducted during 1992 at the Naturita UMTRA Project site or sites associated with this remedial action. It is anticipated that cultural resource surveys will be conducted in 1993 to support planned activities for this site

\subsection{HISTORIC BUILDING INVENTORY RECORDS}

No HBIRs were submitted for VPs associated with the Naturita UMTRA Project site. 


\subsection{RIFLE}

The final EIS for the Old and New Rifle UMTRA Project sites was published in March 1990; the selected remedial action is to relocate all contaminated materials by truck to the Estes Gulch disposal site. Remedial action began in 1992 and is scheduled to be completed in 1996.

\subsection{STATUS OF CULTURAL RESOURCE ACTIVITIES}

No cultural resource activities were conducted for the Rifle site in 1992, and no further cultural resource surveys are planned at this time.

\section{$7.2 \quad$ HISTORIC BUILDING INVENTORY RECORDS}

No HBIRs were submitted for VPs associated with the Rifle UMTRA Project site. 


\subsection{SLICK ROCK}

The draft EA for the North Continent and Union Carbide Slick Rock UMTRA Project sites is due to be completed in 1993. The proposed remedial action is to relocate all contaminated materials by truck to the Burro Canyon disposal site. The remedial action is planned to begin in 1994.

\section{$8.1 \quad$ STATUS OF CULTURAL RESOURCE ACTIVITIES}

No cultural resource activities were conducted during 1992 at the Slick Rock site. Cultural resource surveys are planned for 1993.

\subsection{HISTORIC BUILDING INVENTORY RECORDS}

No HBIRs were submitted for VPs associated with the Slick Rock UMTRA Project sites. 


\subsection{LIST OF CONTRIBUTORS}

The following individuals contributed to the preparation of this report.

\begin{tabular}{ll}
\hline Name & Contribution \\
\hline Southwest Environmental & Overall document authorship \\
C. Slosberg & Text processing \\
D. Thalley & Technical editing \\
\hline
\end{tabular}




\subsection{REFERENCES}

DOE (U.S. Department of Energy), 1984. "Programmatic Memorandum of Understanding," DOE No. DE-GM04-84AL28460, prepared by the U.S. Department of Energy, UMTRA Project Office, Albuquerque Operations Office, Albuquerque, New Mexico.

GRI (Grand River Institute), 1992a. Addendum II, Cultural Resource Inventory Report on the U.S. Department of Energy's Proposed Remedial Actions at Gunnison Uranium Mill Tailings Site Including the Land Fill Disposal Site, the Sixmile Lane Borrow Site, and the Tenderfoot Mountain and Chance Gulch Borrow Site Haul Routes in Gunnison County, Colorado. Declaration of Negative Findings, GRI Project No. 9223, June 15, 1992, prepared by GRI, Grand Junction, Colorado, for MK-Ferguson Company.

GRI (Grand River Institute), 1992b. Preliminary Report on the Evaluative Testing at Site 5GN810 As Part of the U.S. Department of Energy's Proposed Remedial Actions at Gunnison Uranium Mill Tailings Site in Gunnison County, Colorado. GRI Project No. 9222, June 1992, prepared by GRI, Grand Junction, Colorado, for MK-Ferguson Company. 

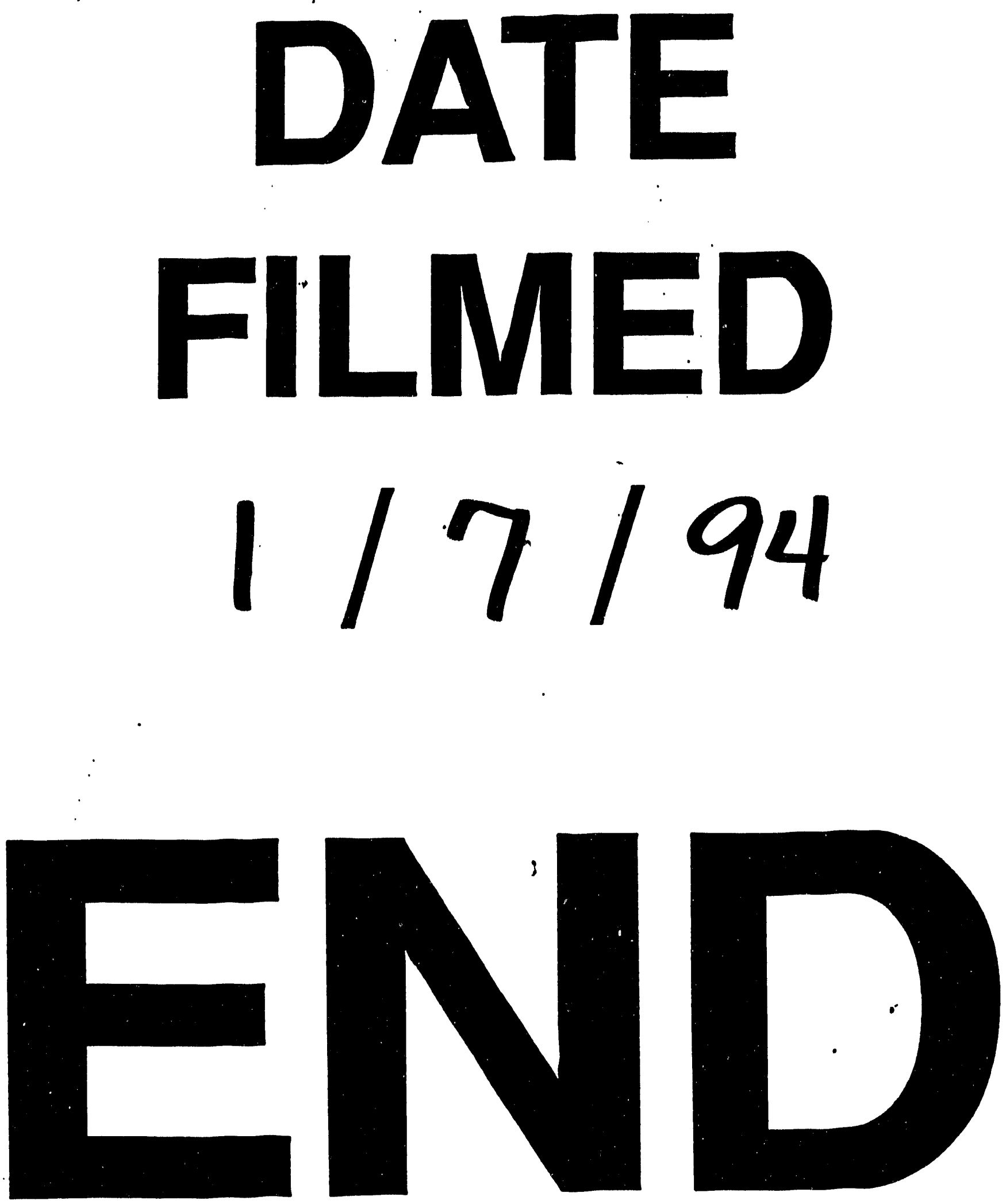
